\title{
DYNAMICS OF COVID-19'S PSYCHOLOGICAL IMPACT IN THE CZECH REPUBLIC: SITUATION DURING SPRING 2020
}

\author{
Iva Stuchliková, Dalibor Kučera, Tomáš Mrhálek, Eva Potužníková, Michaela Plassová
}

\begin{abstract}
The study presents the results of a screening focused on the psychological impact associated with the outbreak and further development of COVID-19 pandemic in the Czech population during March - May 2020. The aim of the study was to investigate temporal dynamics of psychological impact covering the first wave of the epidemic, i.e., first phases of the epidemic growth, culmination, decrease, and slow return to a normal lifestyle. The sample of 2716 respondents aged between 18 and 89 years participated in an online survey from March 18th to May 25th, 2020; part of them (typically seniors and others, who had not access to the internet) were assisted in entering the data by trained interviewers. The survey comprised questionnaires capturing emotional states, psychological disturbance, anxiety, and depression. The changes in the scores by pandemic phase (time frame) were studied for the whole sample and for gender and age groups. The results show that the threat of COVID-19 caused a significant increase in negative emotional experience and in the symptoms of psychological disturbance, anxiety, and depression in the Czech population in time of infection culmination, even when the spread of the pandemic was well controlled, and then a gradual decline over time. The data indicated that the pandemic situation had a more pronounced impact on women and younger adults. The study also showed that in situations of pandemic stress associated with isolation, when isolated people are interviewed about their mental state, their reports on negative experiencing might be significantly reduced compared to direct anonymous selfreports data entry.
\end{abstract}

Keywords: COVID-19, Czech Republic, mental health, first wave, temporal dynamics

Received: 6. 7. 2021

Approved: 23. 11. 2021

Published online: 30. 12. 2021 


\section{Introduction}

COVID-19 has different dynamics in different parts of the world, and countries are taking various measures to try to mitigate and control it. Since 2020, the epicenter of the pandemic has been gradually moving, but even in countries where the onset of the pandemic has been managed, epidemic risks remain. This corresponds to various measures being adopted at the local or national level, epidemiological and psychological impacts of which are intensely studied. Studies from individual countries can provide important information, as both the severity of the epidemic situation and the extent of locally adopted measures to hinder the spread of the disease may vary.

At a time when Europe was beginning to become the epicentre of the pandemic (March 2020), the Czech Republic gradually (from March 10 to 16) adopted strong restrictive measures, including closure of schools, shops and restaurants, ban on sporting, cultural, and other activities, and restrictions on the free movement of persons. On 19 March, all persons were required to wear a face mask outside of their home (Government of the Czech Republic, 2020). These measures were unusually strong in Europe at the time, although they were later adopted in some other European countries, too. However, the measures were successful (in comparison to other European countries, the proportion of infected and deaths was lower) and a massive outbreak of the disease was prevented.

The aim of this research survey was to react as quickly as possible to this unprecedented situation and to begin to capture subjective experiences of Czech people shortly after the start of the measures. On March 18, the data on emotional experiences and symptoms accompanying psychological distress began to be collected via an Internet interface and with the help of trained interviewers.

After the first stage of restrictive measures, which were adopted for a period of three weeks (Government of the Czech Republic, 2020), the restrictions regarding the closure of schools and businesses and limiting the freedom of movement were extended for another three weeks. Although the epidemic numbers were relatively mild at that time (3000 infected and 29 deaths for a population of 10.7 million), the future development was still unclear and people continued to live under protective restrictions implying social isolation, which has been expected to increase the incidence of mental health problems (Twenge \& Joiner, 2020). As the situation had lasted longer and restrictions had been extended, the online survey was slightly enriched by adding a questionnaire with validated cut-off scores for clinical anxiety and depression states since March 30th.

During the ongoing pandemic, a perspective of health risk dominated the media discourse related to protective measures and influenced the view on the most vulnerable subpopulations. People with chronic diseases that could adversely affect the immune response, and older people in general were seen as the most vulnerable (according to specific measures taken in the Czech Republic, the elderly sub-population at higher risk was defined by age 65+). The negative psychological impact of necessary restrictions was not sufficiently considered at that time.

The psychological impacts of the COVID-19 pandemic situation were of interest in many national and international studies. The studies published so far show several psychological consequences, especially at the level of mental health. Elevated levels of distress and anxiety are indicated by studies by Fisher et al. (2020), Al Dhaheri et al. (2021), McCracken et al. (2020), Xiong et al. (2020), Rossi et al. (2020), Talevi et al. (2020), Salari et al. (2020), Gilan 
et al. (2020), Szabó et al. (2020), and Serafini et al. (2020). For example, the level of mental distress in the US population is three times higher than in 2019 or 2018 (Twenge \& Joiner, 2020); more than half of all respondents in a study in China reported a moderate to serious psychological impact (Wang et al., 2020).

Studies addressing the impact on sociodemographic groups show that the most psychologically vulnerable group may not only be the sick or the elderly. Female gender was consistently associated with higher levels of psychological impact (Mazza et al., 2020; Meng et al., 2020; Özdin \& Bayrak Özdin, 2020; Qiu et al., 2020), except in the China study (Wang et al., 2020), which showed greater psychological impact, but lower anxiety, depression, and stress in females. Regarding age, some authors report young adults (Rodríguez-Rey et al., 2020; Twenge \& Joiner, 2020) or students (Wang et al., 2020) are the most affected, others show the highest levels of psychological distress in both young adults and elderly (Qiu et al., 2020). A study focused on the impacts of COVID-19 on elderly people reported depression and anxiety in $37 \%$ of respondents over 60 years of age, but there were no significant differences between age segments of the elderly population (Meng et al., 2020). On the other hand, the young age cohort may be sensitive to some mental health issues only, such as anxiety and stress, but not to others, e.g., depression (Mazza et al., 2020). Studies in the population of young adults (aged 18-24) show relatively large impacts on mental health and related problems, for example, due to substantial lifestyle changes (restrictions on social life), economic insecurity, or limited experience with crisis situations (e.g., Jacques -Aviñó et al., 2020; Banna et al., 2020; Pierce et al., 2020; Tsoukalis-Chaikalis et al., 2021).

The purpose of this study was to provide initial findings on the temporal dynamics of psychological impact on the Czech population in the first phase of the epidemic in 2020, starting from the outbreak of the infection, through the culmination and gradual decrease in the spread of the disease to the slow return to a normal lifestyle. The impact of changing epidemic situation on psychological health is studied, as reflected in emotional well-being, general psychological disturbance, anxiety, and depression scores, as well as the differences of this dynamics for the gender and age groups.

\section{Method \\ Data Collection}

Data collection was organized as an online project, "Research on the Psychological Impacts of the Coronavirus Epidemic in the Czech Republic" (JUPSYCOR; https://www.jupsycor.cz; approved by the Ethics Committee of the Faculty of Education, University of South Bohemia). The open online interface was promoted through social networks and e-mails sent by cooperating institutions. In an effort to obtain data from a broad and diverse sample of respondents, the interface allowed for two ways of data entry. One for individual respondents, who directly filled in their self-report, and the other one for student interviewers who received online training and assisted data entry from other respondents (e.g., respondents who agreed to participate but were not able to fill in the online survey were interviewed in the very same format via a phone call and the interviewer typed the answers into the electronic form). The respondents were fully informed about the nature of the survey and asked for informed consent before participating on a voluntary basis. They provided demographic data, answered three open questions related to their perception and experience of COVID-19 situation (these are not reported in this study), and completed self-reporting questionnaires capturing their emotional 
states in recent days, psychological disturbance symptoms and since March 30th also anxiety and depression levels. The data were collected in 68 days, from March 18 to May 25, 2020, and this period was chosen with respect to the development of pandemic situation in four phases, time frames (see below).

\section{Phases of Development of the Pandemic (Time Frames)}

All survey data were marked in terms of the exact date on which they were collected. These dates were categorized into four "time frames". The time frames were defined according to the development of the epidemic and the protective measures adopted by the government to control its further spread.

Fig. 1 shows an approximate description of the situation in the Czech Republic (during 68 days of the survey together with defined time frames):

1. The epidemic growth time frame (T1): March 18 - March 29: Major emergency measures adopted by March 16 (closure of schools, restaurants, shops, wearing masks order, restrictions of free movement), first deaths of COVID-19 patients

2. The culmination of the disease time frame (T2): March 30 - April 5: Extension of restrictions 3. The decrease of infection time frame (T3): April 6 - April 19: Slight decrease in restrictions (partial release in retail, possibility of individual outdoor sports)

4. Slow return to normal lifestyle (T4): April 20th - May 25th: Significant decrease in restrictions (permission to operate small trades, partial opening of schools, opening of establishments up to $2500 \mathrm{~m}^{2}$ ).

Most of the respondents answered in the second time frame, which was the shortest (7 days). In the second time frame, the HADS questionnaire was also included in the test battery.

Figure 1. Situation milestones and four JUPSYCOR time frames

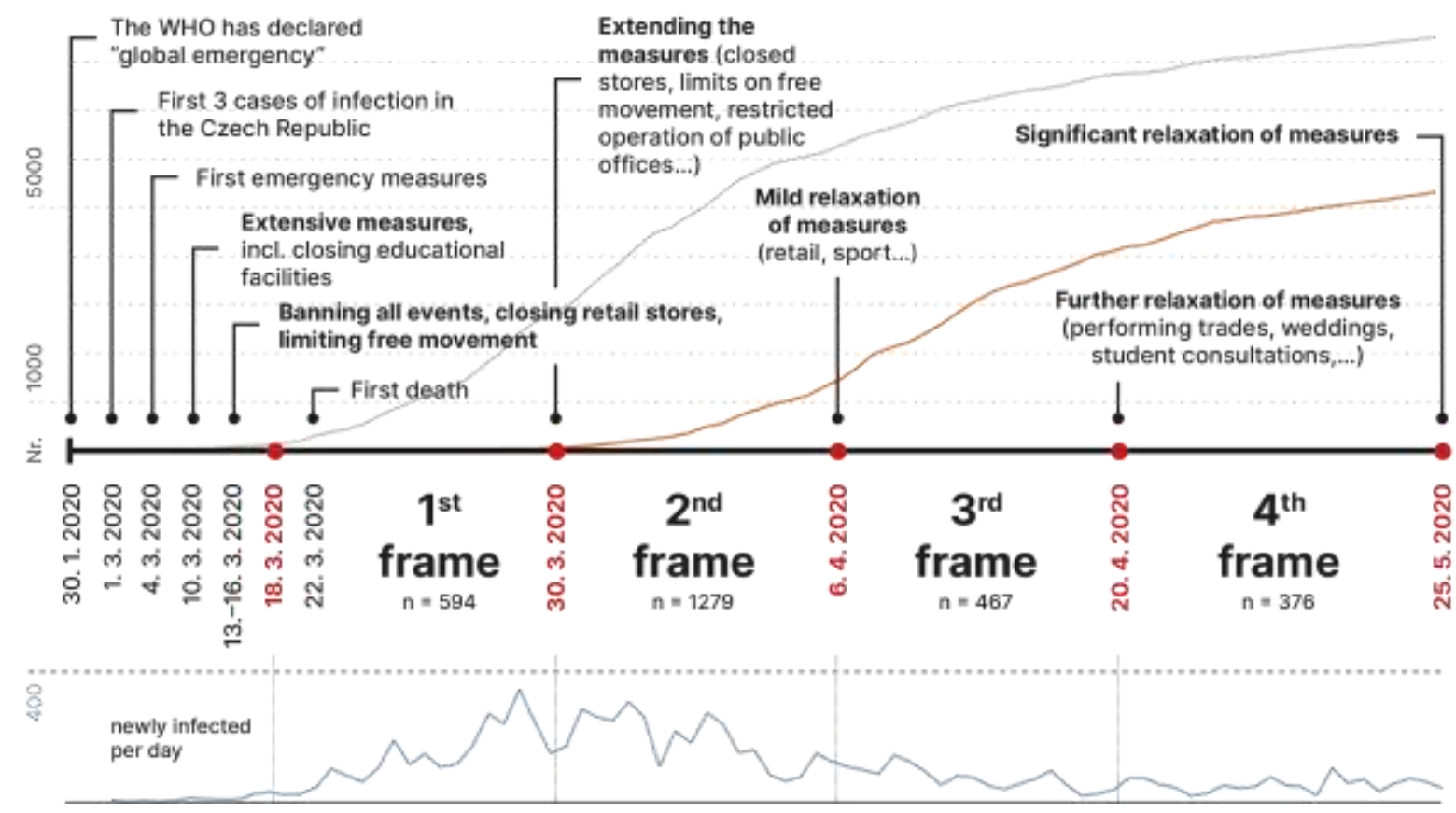




\section{Sample}

A total of $\mathrm{N}=2716$ respondents provided valid responses for the investigation. The research sample consisted of respondents who declared a minimum age of 18 years, agreed to participate and correctly completed the questionnaire set (repeated completions were excluded). Due to the data collection method and limitations caused by the epidemic situation (which made it difficult to collect data, especially from the elderly population), the sample could not be balanced with respect to demographic variables or time of participation. The sample has a significantly higher proportion of women $(78.8 \%)$, young people under 26 years $(43.1 \%)$, persons with tertiary education (38.1\% compared to $22 \%$ as reported by the National Training Fund) (NVF-NOZV, 2016), and the number of respondents who participated in the second time frame (47.1\%), see Table 1.

Table 1. The sample

\begin{tabular}{lll} 
Characteristic & Group & $\mathbf{N}(\boldsymbol{\%})$ \\
\hline Gender & Female & $2139(78.8 \%)$ \\
& Male & $577(21.2 \%)$ \\
& Total & $2716(100 \%)$ \\
\hline Age & Mean (SD) & $36.9(18.1)$ \\
& Min-Max & $18-89$ \\
\hline Education & Primary & $100(3.7 \%)$ \\
& Secondary & $1581(58.2 \%)$ \\
& Tertiary & $1035(38.1 \%)$ \\
\hline Life cycle identity & Student & $988(36.4 \%)$ \\
& Retiree & $384(14.1 \%)$ \\
& Other ${ }^{1}$ & $1344(49.5 \%)$ \\
\hline Time frame & T1 & $594(21.9 \%)$ \\
& T2 & $1279(47.1 \%)$ \\
& T3 & $467(17.2 \%)$ \\
& T4 & $376(13.8 \%)$ \\
\hline
\end{tabular}

${ }^{1}$ The "Other" category includes all other population groups who do not consider themselves a student or retiree (e.g., the economically active population, the unemployed and respondents caring for entrusted persons).

To search for differences in subpopulations' reaction to the pandemic situation, age groups (see Table 2) were created based on life cycle stages (i.e., young people, younger, middle and older productive age, senior age). The group of young people under 26 years (from which $80 \%$ were students) was divided into two subgroups of similar size. This allowed us to gain a more detailed understanding of the psychological impact on the youngest subpopulation, which was identified as the most vulnerable in some recent studies on COVID-19. The percentages of students in the two youngest subgroups were $91.6 \%$ and $71.1 \%$, respectively. To reveal whether the psychological load of the pandemic differs with age, a correlation analysis and separate temporal dynamics analyses for age groups were carried out. As the distribution of gender was heavily unbalanced, men 4 times less represented than women, separate analyses were carried out for women and men subsamples. As the significance of gender differences could not be validly tested in the whole unbalanced sample, a randomly selected stratified and equally sized subgroup of the sample of women $(\mathrm{N}=576)$ was created and used to validate gender 
differences. The assistance of interviewers helped collect data also from people who agreed to participate but were not able or wishing to use the Internet to enter the data directly.

Table 2. Composition of the data sample by age group and gender

\begin{tabular}{lllll} 
Age group & $\mathbf{N}(\boldsymbol{\%})$ & Females $(\%)$ & Males $(\%)$ & Assisted data entry (\%) \\
\hline $18-21$ & $512(18.9 \%)$ & $430(84 \%)$ & $82(16 \%)$ & $96(18 \%)$ \\
$22-25$ & $658(24.2 \%)$ & $524(80 \%)$ & $134(20 \%)$ & $110(17 \%)$ \\
$26-34$ & $421(15.5 \%)$ & $306(73 \%)$ & $115(27 \%)$ & $74(18 \%)$ \\
$35-44$ & $306(11.3 \%)$ & $250(82 \%)$ & $56(18 \%)$ & $50(16 \%)$ \\
$45-64$ & $436(16.1 \%)$ & $338(78 \%)$ & $98(22 \%)$ & $159(22 \%)$ \\
$65+$ & $383(14.1 \%)$ & $291(76 \%)$ & $92(24 \%)$ & $153(43 \%)$ \\
Total & $2716(100 \%)$ & $2139(79 \%)$ & $577(21 \%)$ & $653(24 \%)$ \\
\hline
\end{tabular}

\section{Measures}

SEHW: Scales of Emotional Habitual Subjective Well-being (Džuka \& Dalbert, 2002) is a 10-item questionnaire focused on the emotional component of subjective well-being (Džuka, 2015). It uses the Positive Emotions subscale (SEHW-P) consisting of four descriptors (pleasure, happiness, joy, physical freshness) and the Negative Emotions subscale (SEHW-N) comprising six descriptors (anger, guilt feelings, shame, fear, pain, sorrow), each being assessed on a six-point frequency scale ranging from 1 (almost never) to 6 (almost always). The questionnaire has been used in studies on well-being in different populations (Džuka \& Dalbert, 2002; Gurková et al., 2014). The internal consistency estimate for the positive emotions subscale was Cronbach's alpha $=0.83$ and for the negative emotions subscale it was Cronbach's alpha $=0.67$ in the validation study (Džuka \& Dalbert, 2002). In the present study, the respective Cronbach alphas were 0.85 and 0.74 , the McDonald's omega was 0.85 for positive emotions and 0.76 for negative emotions.

SRQ20: The World Health Organization (WHO) developed the Self-Reporting Questionnaire as a screening tool for common mental disorders in primary health care settings (Harding et al., 1983). The SRQ20 uses 20 items with 2 variants of answer (yes/no) and has been used in numerous settings (community, primary care, hospital) (Beusenberg et al., 1994). The questionnaire was used in many studies, especially for a quick screening of mental problems in emergency and crisis situations and in research in developing countries (Scholte et al., 2011; Ventevogel et al., 2007). The cut-off point of 8 is widely used for total scores (Harpham et al., 2003; Plomecka et al., 2020), since it has been understood that the resulting SRQ20 score falls into three categories: no problems (0 to 4 positive answers), mild difficulties (5-7 positive answers) and severe difficulties (8 or more positive answers) (Dragomirecká et al., 2004). In the present study, Cronbach's alpha was 0.84 and McDonald's omega was 0.85.

HADS: The Hospital Anxiety and Depression Scale (Zigmond \& Snaith, 1983) is a 14-item questionnaire developed to identify the case (possible and probable) of anxiety disorders and depression. It is divided into an Anxiety subscale (HADS-A) and a Depression subscale (HADS-D), both of which contain 7 intermingled items. HADS has been used extensively, and there are several hundreds of studies using HADS as a research instrument (Cosco et al., 2012). Bjelland et al. (Bjelland et al., 2002), through a systematic review of a large sample of studies, identified a cut-off point of 8 (from 21) for anxiety and/or depression. The Czech version 
published by Bužgová et al. (2014) showed acceptable reliability (Cronbach's alpha 0.82 and 0.80 for anxiety and depression scale) and cut-off scores of 8 for mild, 11 for moderate, and 15 for severe anxiety/depression. In the present study the Cronbach alphas were 0.88 for anxiety and 0.78 for depression, McDonald's omega was 0.88 for anxiety and 0.78 for depression.

\section{Data Analysis}

Dependent variables were positive and negative emotions scores based on SEHW, total psychological disturbance score (mental distress) based on SRQ20, and anxiety and depression scores based on HADS; independent variables were gender, age, and time frame.

Statistical analysis was performed using SPSS Statistics, version 24. The reliability of the instruments was tested using Cronbach's alpha and McDonald's omega (Hayes \& Countts, 2020), and the relationships between the individual scales were examined using intercorrelation analysis (see Figure 2). The normality tests did not show a normal distribution (data showed a significant left-hand skewness), nonparametric tests were used: Mann-Whitney U test and Kruskal-Wallis ANOVA. To ensure invariance between the comparison groups, the selected analyses were adjusted to limit other intervening factors. The level of statistical significance was established at $\mathrm{p}<0.05$, two-sided tests were used to test differences.

Figure 2. Dependent variables scales inter-correlation

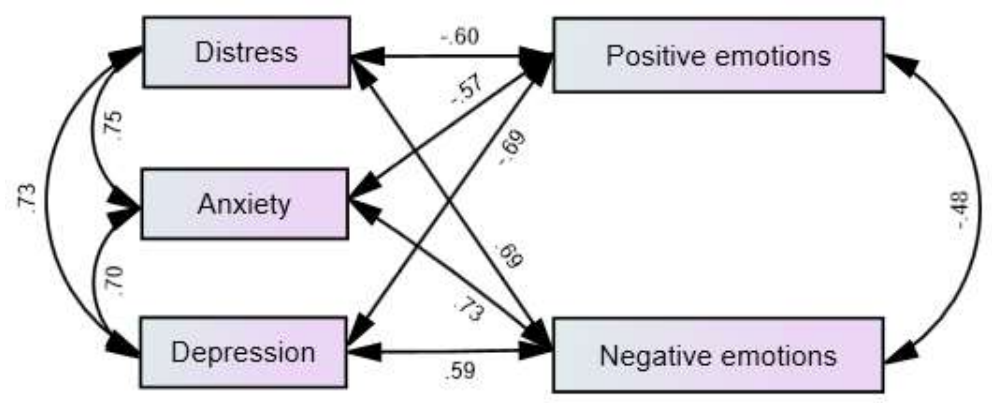

Note. All coefficients are significant at $\mathrm{p}<.001$ (Bonferroni correction).

\section{Results}

\section{Direct self-report and interviewer-assisted self-report}

For hard-to-reach groups of respondents (e.g., in age groups 45-64 and 65+), data collection was performed using the assistance of an interviewer, therefore, the difference to directly entered self-reported data was tested, taking into account age as a covariate. A significant difference after corrections was identified in the case of depression $(\mathrm{F}=26.78, \mathrm{p}<0.01$, $r=.012)$, evaluation of negative emotions $(F=9.49, p<0.01 \mathrm{r}=.004)$ and stress $(\mathrm{F}=9.01$, $\mathrm{p}<0.05), \mathrm{r}=.004$ ) also shows a significant correlation, but with a low strength of the effect.

\section{Temporal Dynamics}

Scores of positive and negative emotions scales, general psychological disturbance, anxiety, and depression were used to analyse the temporal dynamics of self-reported mental states 
during the time frames of the pandemic. Independent samples Kruskal-Wallis test analysis showed significant differences in all these measures between different time frames. Table 4 provides basic descriptives for dependent variables in the four 'time frames' and the results of Kruskal-Wallis analyses (the tests are validated on a sample with only direct self-report data).

Table 3. Temporal dynamics of psychological impact by time frame

\begin{tabular}{|c|c|c|c|c|c|c|c|c|}
\hline & $\begin{array}{l}\text { Time } \\
\text { frame }\end{array}$ & $\begin{array}{l}\text { Mean } \\
\text { (SD) }\end{array}$ & $\begin{array}{l}95 \% \\
\text { CI }\end{array}$ & $\begin{array}{l}\text { Median } \\
(\text { IQR })\end{array}$ & $\begin{array}{l}\text { Kruskal- } \\
\text { Wallis X }^{2}\end{array}$ & Sig. & Pairwise $^{\mathrm{a}}$ & $\begin{array}{l}\text { Effect } \\
\text { size } \\
\text { Eta }^{2} \\
\end{array}$ \\
\hline \multirow{6}{*}{$\begin{array}{l}\text { Positive } \\
\text { emotions } \\
\text { (SEHW-P) }\end{array}$} & $\mathrm{T} 1$ & $\begin{array}{l}3.43 \\
(0.99)\end{array}$ & $\begin{array}{l}3.35- \\
3.51\end{array}$ & $\begin{array}{l}3.25 \\
(1.25)\end{array}$ & 23.28 & $<0.01$ & $\mathrm{~T} 1>\mathrm{T} 4 *$ & 0.007 \\
\hline & $\mathrm{T} 2$ & $\begin{array}{l}3.37 \\
(0.94)\end{array}$ & $\begin{array}{l}3.32- \\
3.42\end{array}$ & $\begin{array}{l}3.35 \\
(1.25)\end{array}$ & $\mathrm{df}=3$ & & $\mathrm{~T} 2<\mathrm{T} 3 *, \mathrm{~T} 4 * *$ & \\
\hline & $\mathrm{T} 3$ & $\begin{array}{l}3.51 \\
(0.97)\end{array}$ & $\begin{array}{l}3.43- \\
3.59\end{array}$ & $3.5(1.0)$ & & & & \\
\hline & 13 & $\begin{array}{l}(0.92) \\
3.61\end{array}$ & $\begin{array}{l}3.59 \\
3.52-\end{array}$ & 3.5 & & & $(\mathrm{~T} 2<\mathrm{T} 3 *$ & \\
\hline & $\mathrm{T} 4$ & $(0.97)$ & 3.71 & $(1.25)$ & $(23.50)^{\mathrm{b}}$ & $(<0.01)^{\mathrm{b}}$ & $\mathrm{T} 4 * *)$ & 0.007 \\
\hline & $\begin{array}{l}\text { Time } \\
\text { frame }\end{array}$ & $\begin{array}{l}\text { Mean } \\
\text { (SD) }\end{array}$ & $\begin{array}{l}95 \% \\
\text { CI }\end{array}$ & & $\mathbf{X}^{2}$ & Sig. & Pairwise $^{a}$ & \\
\hline \multirow{7}{*}{$\begin{array}{l}\text { Negative } \\
\text { emotions } \\
(\mathrm{SEHW}-\mathrm{N})\end{array}$} & $\mathrm{T} 1$ & $\begin{array}{l}2.35 \\
(0.74)\end{array}$ & $\begin{array}{l}2.29- \\
2,41\end{array}$ & $\begin{array}{l}2.33 \\
(1.0)\end{array}$ & 33.50 & $<0.01$ & $\mathrm{~T} 1>\mathrm{T} 4 *$ & 0.011 \\
\hline & $\mathrm{T} 2$ & $\begin{array}{l}2.46 \\
(0.80)\end{array}$ & $\begin{array}{l}2.42- \\
2.50\end{array}$ & $\begin{array}{l}2.33 \\
(1.17)\end{array}$ & $\mathrm{df}=3$ & & $\mathrm{~T} 2>\mathrm{T} 3 *, \mathrm{~T} 4 * *$ & \\
\hline & & 2.30 & $2.22-$ & 2.17 & & & & \\
\hline & $\mathrm{T} 3$ & $(0.76)$ & 2.36 & $(1.0)$ & & & & \\
\hline & & 2.22 & $2.14-$ & 2.17 & & & & \\
\hline & $\mathrm{T} 4$ & $(0.73)$ & 2.29 & $(1.0)$ & $(30.58)^{b}$ & $(<0.01)^{\mathrm{b}}$ & $(\mathrm{T} 2<\mathrm{T} 3 *, \mathrm{~T} 4 * *)$ & 0.012 \\
\hline & $\begin{array}{l}\text { Time } \\
\text { frame }\end{array}$ & $\begin{array}{l}\text { Mean } \\
\text { (SD) }\end{array}$ & $\begin{array}{l}95 \% \\
\text { CI }\end{array}$ & & $\mathbf{X}^{2}$ & Sig. & Pairwise $^{a}$ & \\
\hline \multirow{6}{*}{$\begin{array}{l}\text { Psychological } \\
\text { disturbance } \\
\text { (SRQ20) }\end{array}$} & $\mathrm{T} 1$ & $\begin{array}{l}4.74 \\
(3.72)\end{array}$ & $\begin{array}{l}4.44- \\
5.04\end{array}$ & & 44.64 & $<0.01$ & $\mathrm{~T} 1>\mathrm{T} 4 *$ & 0.015 \\
\hline & $\mathrm{T} 2$ & $\begin{array}{l}5.48 \\
(4.34)\end{array}$ & $\begin{array}{l}5.24- \\
5.72\end{array}$ & $5(7)$ & $\mathrm{df}=3$ & & $\begin{array}{l}\mathrm{T} 2>\mathrm{T} 1 * * \mathrm{~T} 3 * * \\
\mathrm{~T} 4 * *\end{array}$ & \\
\hline & & 4.43 & $4.07-$ & $4(6)$ & & & & \\
\hline & $\mathrm{T} 3$ & $(3.95)$ & 4.79 & & & & & \\
\hline & $\mathrm{T} 4$ & $\begin{array}{l}4.03 \\
(3.77)\end{array}$ & $\begin{array}{l}3.65- \\
4.42\end{array}$ & $3(5)$ & $(47.28)^{\mathrm{b}}$ & $(<0.01)^{\mathrm{b}}$ & $\begin{array}{l}(\mathrm{T} 1>\mathrm{T} 4 * * ; \mathrm{T} 2 \\
>\mathrm{T} 3 * *, \mathrm{~T} 4 * *)\end{array}$ & 0.019 \\
\hline & $\begin{array}{l}\text { Time } \\
\text { frame }\end{array}$ & $\begin{array}{l}\text { Mean } \\
\text { (SD) }\end{array}$ & $\begin{array}{l}95 \% \\
\text { CI }\end{array}$ & & $\mathbf{X}^{2}$ & Sig. & Pairwise $^{\text {a }}$ & \\
\hline \multirow{5}{*}{$\begin{array}{l}\text { Depression } \\
\text { (HADS-D) }\end{array}$} & $\mathrm{T} 2$ & $\begin{array}{l}5.71 \\
(3.92)\end{array}$ & $\begin{array}{l}5.49- \\
5.92\end{array}$ & $5(5)$ & 21.34 & $<0.01$ & $\begin{array}{l}\mathrm{T} 2>\mathrm{T} 3 * *, \mathrm{~T} 4 \\
* *\end{array}$ & 0.009 \\
\hline & $\mathrm{T} 3$ & $\begin{array}{l}5.08 \\
(3.69)\end{array}$ & $\begin{array}{l}4.75- \\
5.42\end{array}$ & $4(6)$ & $\mathrm{df}=2$ & & & \\
\hline & & 4.83 & $4.45-$ & $4(5)$ & & & & \\
\hline & $\mathrm{T} 4$ & (3.79) & 5.22 & & $(22.88)^{\mathrm{b}}$ & $(<0.01)^{\mathrm{b}}$ & $(\mathrm{T} 2>\mathrm{T} 4 * *)$ & 0.010 \\
\hline & $\begin{array}{l}\text { Time } \\
\text { frame }\end{array}$ & $\begin{array}{l}\text { Mean } \\
\text { (SD) }\end{array}$ & $\begin{array}{l}95 \% \\
\text { CI }\end{array}$ & & $\mathbf{X}^{2}$ & Sig. & Pairwise $^{\mathrm{a}}$ & \\
\hline \multirow{3}{*}{$\begin{array}{l}\text { Anxiety } \\
\text { (HADS-A) }\end{array}$} & $\mathrm{T} 2$ & $\begin{array}{l}7.01 \\
(4.67)\end{array}$ & $\begin{array}{l}6.75- \\
7.27\end{array}$ & $7(7)$ & 29.24 & $<0.01$ & $\mathrm{~T} 2>\mathrm{T} 3 * *, \mathrm{~T} 4 * *$ & 0.013 \\
\hline & $\mathrm{T} 3$ & $\begin{array}{l}6.11 \\
(4.33)\end{array}$ & $\begin{array}{l}5.72- \\
6.51\end{array}$ & $6(7)$ & $\mathrm{df}=2$ & & & \\
\hline & $\mathrm{T} 4$ & $\begin{array}{l}5.70 \\
(4.24)\end{array}$ & $\begin{array}{l}5.27- \\
6.13\end{array}$ & $5(6)$ & $(2935)^{\mathrm{b}}$ & $(<0,01)^{b}$ & $\begin{array}{l}(\mathrm{T} 2>\mathrm{T} 3 * \\
\mathrm{T} 4 * *)\end{array}$ & 0.013 \\
\hline
\end{tabular}


Table 4 presents the prevalence of mental health problems (for measures with predefined cutoff scores) during the pandemic showing the peak of psychological disturbance in $\mathrm{T} 2$ and improvement in all three measures (psychological disturbance, anxiety, depression) after the culmination of the disease. The classification of the severity of mental health problems is based on work of Dragomirecká et al. (2004) and Bužgová et al. (2014). Differences in time course were significant, also in the subsample with only direct self-reported data.

Table 4. Mental health problems in different time frames

Psychological disturbance (SRQ20)

\begin{tabular}{lllll}
\hline Time frame & No problem & Mild difficulties & Severe difficulties & \\
\hline T1 & $54.5 \%(324 / 310.8)$ & $25.4 \%(151 / 133.8)$ & $20.0 \%(119 / 149.4)$ & - \\
T2 & $47.5 \%(607 / 669.2)$ & $21.5 \%(275 / 288.2)$ & $31.0 \%(397 / 321.6)$ & - \\
T3 & $54.2 \%(253 / 244.3)$ & $25.1 \%(117 / 105.2)$ & $20.8 \%(97 / 117.4)$ & - \\
T4 & $63.0 \%(237 / 196.7)$ & $18.4 \%(69 / 84.7)$ & $18.6 \%(70 / 94.6)$ & - \\
\hline
\end{tabular}

Chi square $=55.70, \mathrm{df}=6, \mathrm{p}<0.001$, Cramer's $\mathrm{V}=0.101$

\begin{tabular}{lllll}
\multicolumn{1}{l}{ Depression (HADS-D) } \\
\hline Time frame & No problem & Mild depression & Moderate depression & Severe depression \\
\hline T2 & $70.3 \%(899 / 925.2)$ & $16.4 \%(210 / 204.9)$ & $10.9 \%(139 / 121.1)$ & $2.4 \%(31 / 27.7)$ \\
T3 & $74.7 \%(349 / 337.8)$ & $15.8 \%(74 / 74.8)$ & $8.4 \%(39 / 44.2)$ & $1.1 \%(5 / 10.1)$ \\
T4 & $76.3 \%(287 / 272)$ & $14.9 \%(56 / 62.5)$ & $6.1 \%(23 / 35.6)$ & $2.7 \%(10 / 8.1)$ \\
\hline
\end{tabular}

Chi square $=17.11, \mathrm{df}=6, \mathrm{p}=0.009$, Cramer's V $=0.086$

\begin{tabular}{lllll}
\multicolumn{4}{l}{ Anxiety (HADS-A) } \\
\hline Time frame & No problem & Mild anxiety & Moderate anxiety & Severe anxiety \\
\hline T2 & $56.7 \%(725 / 776)$ & $20.3 \%(260 / 250.7)$ & $15.9 \%(203 / 174.2)$ & $7.1 \%(91 / 77.8)$ \\
T3 & $64.2 \%(300 / 283.5)$ & $19.9 \%(93 / 91.6)$ & $11.8 \%(55 / 63.6)$ & $4.1 \%(19 / 28.4)$ \\
T4 & $69.9 \%(263 / 228.2)$ & $16.8 \%(63 / 73.7)$ & $8.2 \%(31 / 51.2)$ & $5.1 \%(19 / 22.9)$ \\
\hline
\end{tabular}

Note. Values in parentheses show \% frequency (counts observed/expected)

To summarize the findings of temporal dynamics, the peak of negative experience was reported during the culmination time frame (T2), the two following time frames, i.e., decrease in infection (T3) and slow return to normal lifestyle (T4), were accompanied by a significant decrease in negative and increased positive emotions and relief from psychological disturbances/mental distress, anxiety and depression symptoms (see Fig. 2). While the temporal dynamics of subjective experience, in general, reflected the development of the epidemic, positive emotions scores were still higher than negative emotions scores in each of the time frames. 
Figure 2. Mental health problems observed in the three 'time frames' (four in distress), represented proportionally to the maximum value of the scales of distress, depression, and anxiety.
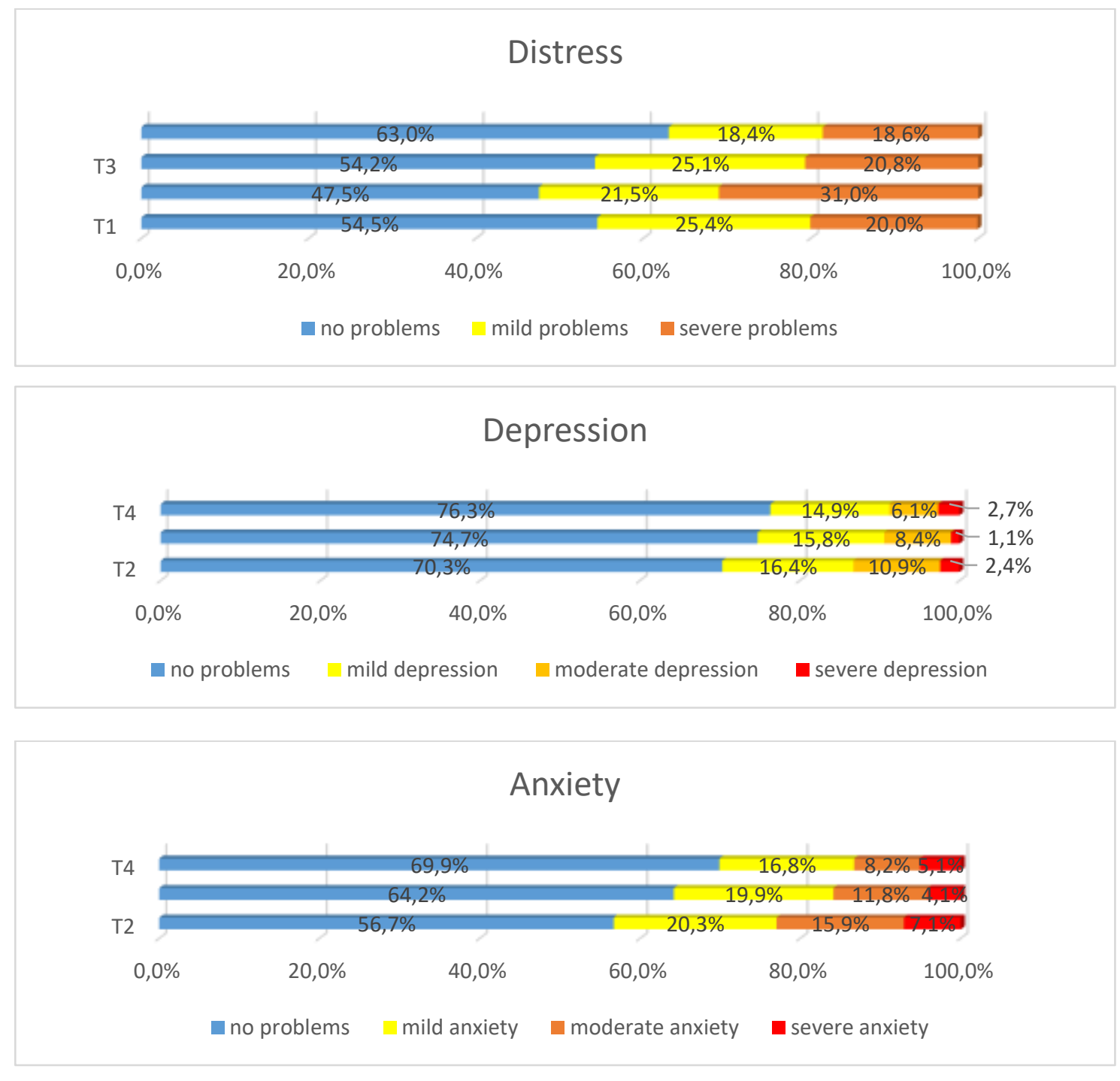

Concerning the content of emotional experience, fear was reported as the strongest negative emotion and in T2 it was significantly stronger than all other negative emotions (Friedman's test $=1973.79, \mathrm{df}=5, \mathrm{p}<0.001$ ), in other time frames its intensity was indistinguishable from sorrow, all other negative emotions were weaker. Anger was the third most reported emotion. Among positive emotions, joy was the strongest emotion reported in T1-T3, while physical freshness was the weakest in T2 and T3; at T4, all positive emotions were reported with similar intensity. Regarding items related to psychological disturbance/mental distress (SRQ20), the most frequently reported symptom was nervousness (reported by $54.6 \%$ of all respondents), being easily tired (47.7\%), lack of enjoyment (42.2\%), poor sleep, and permanent tiredness (34.3\%). Except for five symptoms (bad appetite, difficulty making decisions, imagery of suicide, upset stomach and getting easily tired), all other symptoms changed significantly during the development of the epidemic, the majority of them had a peak in T2 and then decreased. 


\section{Age Group Differences}

The effect of age was analysed with control of 'gender' and 'time frame' variables. Age is significantly and negatively correlated here after Bonferoni correction with negative emotions (Spearman rho $=-0.081, \mathrm{p}<0.01)$ and psychological disturbance $($ rho $=-0.139, \mathrm{p}<0.01)$. However, separate analysis for individual time frames revealed that the significance of these correlations vary and only the correlation of age and psychological disturbance (SRQ20) remains highly significant in all time frames (Spearman's rho ranged from - 0.139 to - 0.173 , with $\mathrm{p}$ values 0.01 or lower after corrections). The subsequent Kruskal-Wallis tests allowed us to specify for each time frame which age groups differ significantly (Table 5). Young adults (age cohorts of 18 - 21 years and 22 - 25 years) showed a higher psychological disturbance from T1 to T3, the group of 22-25 showed a significantly higher level of anxiety in T4 than seniors $(65+$ years $)$.

Table 5. Age group differences in different time frames

\begin{tabular}{|c|c|c|c|c|}
\hline $\begin{array}{l}\text { Time } \\
\text { frame }\end{array}$ & Scale across Age group & $\begin{array}{l}\text { Kruskal-Wallis Sig } \\
\text { (df 5; } X^{2} 2 \text {-way) }\end{array}$ & & Pairwise $^{\mathrm{a}}$ \\
\hline \multirow{6}{*}{$\begin{array}{l}T 1 \\
N=594 \\
(N=255)\end{array}$} & Positive emotions & 7.63 & .534 & \multirow{6}{*}{$\begin{array}{l}18-21>26-34 * *, 35- \\
44 * *, 45-64 *(18-21>35- \\
\left.44^{*}\right)^{\mathrm{b}}\end{array}$} \\
\hline & Negative emotions & 10.63 & 1.77 & \\
\hline & Psychological disturbance & $22.79(14.36)^{b}$ & $<.01(.039)^{\mathrm{b}}$ & \\
\hline & & & & \\
\hline & Anxiety & - & - & \\
\hline & Depression & - & - & \\
\hline \multirow{6}{*}{$\begin{array}{l}\mathrm{T} 2 \\
\mathrm{~N}=1279 \\
(\mathrm{~N}=1127)\end{array}$} & Positive emotions & 5.05 & 2.50 & \multirow{6}{*}{$\begin{array}{l}18-21>45-64 * ; 22-25> \\
35-44 *, 45-64 * *(22-25 \\
\left.>35-44^{*}, 45-64 * *\right)^{\mathrm{b}}\end{array}$} \\
\hline & Negative emotions & 8.81 & .585 & \\
\hline & Psychological disturbance & $24.81(-21.08)^{b}$ & $<.01(<.01)^{b}$ & \\
\hline & & & & \\
\hline & Anxiety & 9.31 & .485 & \\
\hline & Depression & 6.77 & 1.19 & \\
\hline \multirow{5}{*}{$\begin{array}{l}\mathrm{T} 3 \\
\mathrm{~N}=467 \\
(\mathrm{~N}=343)\end{array}$} & Positive emotions & 5.13 & 2.00 & \multirow{5}{*}{$\begin{array}{l}\left(65+<22-25^{*}, 26-34^{*}\right)^{\mathrm{b}} \\
65+<18-21^{*}(65+<18- \\
\left.21^{* *}, 22-25^{* *}, 26-34^{*}\right)^{\mathrm{b}}\end{array}$} \\
\hline & Negative emotions & $4.89(13.46)^{b}$ & $2.15(.095)^{b}$ & \\
\hline & Psychological disturbance & $14.98(18.88)^{\mathrm{b}}$ & $.050(.010)^{\mathrm{b}}$ & \\
\hline & Anxiety & 5.78 & 1.65 & \\
\hline & Depression & 4.85 & 2.17 & \\
\hline \multirow{5}{*}{$\begin{array}{l}\mathrm{T} 4 \\
\mathrm{~N}=376 \\
(\mathrm{~N}=338)\end{array}$} & Positive emotions & 6.34 & 1.35 & \multirow{5}{*}{$(22-25>65+*)^{b}$} \\
\hline & Negative emotions & $8.56(12.92)^{b}$ & $.64(.12)^{b}$ & \\
\hline & Psychological disturbance & $16.14(14.50)^{b}$ & $.03(.07)^{\mathrm{b}}$ & \\
\hline & Anxiety & $13759(12.16)^{b}$ & $.48(.17)^{\mathrm{b}}$ & \\
\hline & Depression & 44472 & 3.42 & \\
\hline
\end{tabular}

${ }^{a}$ Bonferroni correction - significance at rate $* \mathrm{p}<.05 ; * * \mathrm{p}<.01$.

${ }^{\mathrm{b}}$ Values in parentheses are adjusted for directly self-reported data only.

Note. Effect size Eta squared for all tests below .01 (small effect).

\section{Gender Differences}

Gender differences were assessed using the Mann-Whitney U test for the whole sample and for individual data collection time frames. The results show that except for positive emotions, women had significantly higher scores since the start of the epidemic, through it resulting in 
decreased infection (time frames $\mathrm{T} 1$ to $\mathrm{T} 3$ ), in the final time frame (T4 return to normal lifestyle) only differences in negative emotions and anxiety remained significant.

As the gender distribution was heavily unbalanced, a stratified subgroup of equally sized randomly selected women's sample $(\mathrm{N}=576)$ was used to create a balanced subsample $(\mathrm{N}=1152)$ to validate the findings. The means of dependent variables of the randomly selected female subgroup were within $95 \%$ CI of the original women's sample and the distribution was comparable. The only different result of the tests was found for negative emotions in T4, where the balanced subsample $(\mathrm{N}=1152)$ also produced a significantly higher score for women (see Table 6).

Table 6. Gender differences in different time frames

\begin{tabular}{|c|c|c|c|c|c|c|c|c|}
\hline $\begin{array}{l}\text { Time } \\
\text { frame }\end{array}$ & Scales & MALE & & FEMALE & & $\begin{array}{l}\text { Mann- } \\
\text { Wh. U }\end{array}$ & $\mathbf{Z}$ & $\begin{array}{l}\text { Sig. } \\
\text { (2-way) }\end{array}$ \\
\hline & & Mean (SD) & $\begin{array}{l}\text { Median } \\
(\text { IQR })^{\mathrm{a}}\end{array}$ & Mean (SD) & $\begin{array}{l}\text { Median } \\
(I Q R)^{a}\end{array}$ & & & \\
\hline \multirow{5}{*}{$\mathrm{T} 1$} & $\begin{array}{l}\text { Positive } \\
\text { emotions }\end{array}$ & $3.55(0.96)$ & $3.5(1.25)$ & $3.38(1.00)$ & $\begin{array}{l}3.25 \\
(1.25)\end{array}$ & 30713 & -1.81 & .231 \\
\hline & $\begin{array}{l}\text { Negative } \\
\text { emotions }\end{array}$ & $2.05(0.74)$ & $\begin{array}{l}1.83 \\
(0.83)\end{array}$ & $2.46(0.71)$ & $\begin{array}{l}2.33 \\
(0.83)\end{array}$ & 21513 & -6.83 & $<.01$ \\
\hline & $\begin{array}{l}\text { Psychological } \\
\text { disturbance }\end{array}$ & $3.22(3.17)$ & $2(4)$ & $5.28(3.76)$ & $5(5)$ & 21937 & -6.61 & $<.01$ \\
\hline & Anxiety & - & - & - & - & - & - & - \\
\hline & Depression & - & - & - & - & - & - & - \\
\hline \multirow{5}{*}{$\mathrm{T} 2$} & $\begin{array}{l}\text { Positive } \\
\text { emotions }\end{array}$ & $3.46(0.95)$ & $\begin{array}{l}3.50 \\
(1.25)\end{array}$ & $3.35(0.94)$ & $\begin{array}{l}3.25 \\
(1.25)\end{array}$ & 108955 & -2.08 & .29 \\
\hline & $\begin{array}{l}\text { Negative } \\
\text { emotions }\end{array}$ & $2.11(0.82)$ & $2(1)$ & $2.53(0.78)$ & $2.50(1)$ & 79651 & -7.89 & $<.01$ \\
\hline & $\begin{array}{l}\text { Psychological } \\
\text { disturbance }\end{array}$ & $3.94(3.91)$ & $3(5)$ & $5.81(4.36)$ & $5(7)$ & 88094 & -6.22 & $<.01$ \\
\hline & Anxiety & $5.33(4.40)$ & $4(6)$ & $7.37(4.65)$ & $7(7)$ & 87606 & -6.31 & $<.01$ \\
\hline & Depression & $4.74(3.69)$ & $4(5)$ & $5.92(3.94)$ & $5(6)$ & 97762 & -4.30 & $<.01$ \\
\hline \multirow{5}{*}{ T3 } & $\begin{array}{l}\text { Positive } \\
\text { emotions }\end{array}$ & $3.59(0.90)$ & $\begin{array}{l}3.50 \\
(1.25)\end{array}$ & $3.48(0.93)$ & $3.5(1)$ & 20653 & -.80 & 2.11 \\
\hline & $\begin{array}{l}\text { Negative } \\
\text { emotions }\end{array}$ & $2.02(0.71)$ & $2(1)$ & $2.40(0.76)$ & $2.33(1)$ & 15230 & -4.98 & $<.01$ \\
\hline & $\begin{array}{l}\text { Psychological } \\
\text { disturbance }\end{array}$ & $3.11(3.27)$ & $2(6)$ & $4.93(4.08)$ & $5(6)$ & 15937 & -4.46 & $<.01$ \\
\hline & Anxiety & $4.50(3.78)$ & $3(7)$ & $6.72(4.38)$ & $6(6)$ & 15328 & -4.91 & $<.01$ \\
\hline & Depression & $4.11(3.33)$ & $3(5)$ & $5.45(3.75)$ & $5(5)$ & 17037 & -3.60 & $<.01$ \\
\hline \multirow{5}{*}{$\mathrm{T} 4$} & $\begin{array}{l}\text { Positive } \\
\text { emotions }\end{array}$ & $3.70(0.87)$ & $\begin{array}{l}3.75 \\
(1.25)\end{array}$ & $3.60(0.99)$ & $\begin{array}{l}3.5 \\
(1.25)\end{array}$ & 9710 & -.80 & 2.13 \\
\hline & $\begin{array}{l}\text { Negative } \\
\text { emotions }\end{array}$ & $1.94(0.58)$ & $\begin{array}{l}1.83 \\
(0.83)\end{array}$ & $2.28(0.74)$ & $\begin{array}{l}2.17 \\
(0.92)\end{array}$ & $\begin{array}{l}7607 \\
(5243)^{\mathrm{a}}\end{array}$ & $\begin{array}{l}-3.41 \\
(-3.24)^{b}\end{array}$ & $\begin{array}{l}2.13 \\
(<.01)^{\mathrm{b}}\end{array}$ \\
\hline & $\begin{array}{l}\text { Psychological } \\
\text { disturbance }\end{array}$ & $3.33(3.04)$ & $3(4)$ & $4.19(3.90)$ & $4(5)$ & 9293 & -1.32 & .93 \\
\hline & Anxiety & $4.07(3.06)$ & $4(4)$ & $6.05(4.38)$ & $5(6)$ & 7628 & -3.36 & $<.01$ \\
\hline & Depression & $4.51(3.51)$ & $4(4)$ & $4.90(3.85)$ & $4(5)$ & 9868 & -.56 & 2.87 \\
\hline
\end{tabular}

a IQR = interquartile range

b Values in parentheses are adjusted for directly self-reported data only.

Note. Effect size Eta squared ranging from 0.03 to 0.05 for all tests in T2-T4 (small effect). In T1 Eta squared $=0.01$ for positive emotions (small effect), 0.07 for psychological disturbance and 0.08 negative emotions (both intermediate effect).

The p-values corrected with Bonferroni correction. 
Women reported significantly higher negative and significantly lower positive emotions and greater psychological disturbance, anxiety, and depression. Concerning gender differences in particular time frames, women's experience was significantly more negative than men in T1, $\mathrm{T} 2$, and T3 (the epidemic growth time frame, the culmination and the decrease in infection) and women also showed higher scores of psychological disturbance, anxiety, and depression (the latter two have been measured since T2). In T4 (slow return to normal lifestyle), the gender difference was significant only for negative emotions and anxiety (still higher for women). The effect size was nevertheless very small for all measures (R2 ranged 3-8\%), which shows that gender explained a very small proportion of individual differences in dependent variables.

\section{Discussion}

This study presents data from an online survey aimed at describing the temporal dynamics of subjective experience during the development of an epidemic situation in Spring 2020 in the Czech Republic, today referred to as the first wave of the epidemic. Due to the data collection method, there was an oversampling of women, people with higher education, and young adults, mostly students, and therefore the results must be interpreted carefully with respect to possible selection bias. On the other hand, most of the studies addressing the immediate impact of COVID-19 used a similar sampling method and faced the same problem (Mazza et al., 2020; Wang et al., 2020). This sample composition reflects the population's relationship to the digital world, with young people searching for information more online (Orben et al., 2020). An interesting comparison comes with the study by Plomecka et al. (2020) which was carried out on 12,817 respondents in 12 countries. The sample parameters largely correspond to ours, i.e., there was also an unbalanced sample when $72 \%$ were women and $75 \%$ of the respondents had higher education (bachelor's degree or more). Compared to other studies (Özdin \& Bayrak Özdin, 2020; Rodríguez-Rey et al., 2020), our study succeeded in reaching a relatively large number of seniors over 65 years of age $(14.1 \%)$

The findings of the present study document the time course of the respondents' reaction to the development of the pandemic situation. They indicate that the public experience reflected the worsening of the epidemic situation and the measures taken by the government relatively accurately. The growing infection and the culmination of the disease were reflected in higher values of negative emotions and psychological disturbances, anxiety, and depression. This course is also documented by other published studies, e.g., Fisher et al., 2020, McCracken et al. (2020), Rossi et al. (2020), Salari et al. (2020), and Serafini et al. (2020), which point to a general trend across different countries of the world.

From the point of view of the Czech context, our results can be supported by the study by Trnka and Lorencová (2020), which document the states of fear, anger, and hopelessness of the Czech population. In terms of international comparison, the study of Lieberoth et al. (2021) points to the comparability of the mental state of the population in the Czech Republic in comparison with other European countries (except from, e.g., the UK and Spain, for which significantly higher levels of stress have been documented). It is important to remind the reader that the epidemic situation in the Czech Republic was not overly serious, but the restrictions were timely and widespread. The spread of the epidemic began to be controlled, the capacity of health care was sufficient, and the system worked well. The people of the Czech Republic had a very high confidence in the health care system (Soukup \& Rabušic, 2020), which could 
mitigate the psychological impact of the pandemic. Although, the data indicate that the public responded to the development of the situation with significant changes in emotional well-being, growth in dysphoric feelings, and psychological disturbances. On the other hand, when it was clear that the situation was being managed and the powerful restrictive measures (closure of shops, restriction of free movement) began to loosen, the recovery process was relatively fast and a decrease in psychological disturbance and improved emotional balance was evident at the end of the studied period. This time course is especially evident in the youngest age cohort $18-21$, where joy and happiness increased significantly in T3 and T4, and their psychological disturbance (highest in previous time frames) returned to levels comparable with other age cohorts.

Regarding emotional experience, the analysis across the four 'time frames' proved increased levels of negative emotions and decreased levels of positive emotions during the growth and culmination of the disease compared to later phases of return to a normal lifestyle. However, the scores of positive and negative emotions collected in the two initial time frames characterized by epidemic growth and severe protective restrictions fall in the ranges reported in studies of subjective well-being in situations not affected by COVID-19 or other critical events (Džuka \& Dalbert, 2002; Gurková et al., 2014) and did not indicate a serious emotional reaction to the coronavirus pandemic. This might be caused by the fact that only some negative emotions were elevated, esp. fear and sorrow, which did not lead to a significant increase in the composite negative emotions score. The fear reported can be attributed to concerns about infection. Another survey of the Czech population found that $40 \%$ of respondents feared that they or their loved ones would receive COVID-19 with severe symptoms (Soukup \& Rabušic, 2020).

The impact of the pandemic on psychological disturbances was assessed by SRQ20 similarly to a multinational study (12 countries) by Plomecka et al. (2020) and by HADS as in the Turkish study by Özdin and Bayrak Özdin (2020). A direct comparison with the first study is difficult due to the unavailability of raw scores for individual countries in the research documentation. The published mean scores for men 5.29 ( $\mathrm{SD}=4.64)$ and women 7.62 $(\mathrm{SD}=5.05)$ are nevertheless higher than in our case: $3.49(\mathrm{SD}=3.50)$ and $5.33(\mathrm{SD}=4.17)$. The data on HADS are more comparable, the mean scores for Turkish (Özdin \& Bayrak Özdin, 2020) and Czech data presented are $6.8(\mathrm{SD}=4.2)$ and 6. $55(\mathrm{SD}=4.57)$ for anxiety and 6.7 $(\mathrm{SD}=4.2)$, and $5.39(\mathrm{SD}=3.87)$ for depression. This suggests a less serious impact on the Czech population compared to other countries. However, the percentage of Czechs showing psychological disturbances, anxiety, and depression symptoms is still notable, considering that the spread of the epidemic was relatively well controlled.

Another important finding of the current study relates to the role of social desirability in monitoring the public response to the epidemic. The results indicate that the psychological disturbance scores $(r=.004)$, negative emotions $(r=0.004)$, but especially depression $(r=0.012)$ were significantly lower when the self-report was assisted by the interviewers compared to direct answering through the online interface themselves. Other authors consider a similar influence, such as Plomecka et al. (2020), but to our knowledge, this difference has not been empirically documented. The fact that negative experience scores are reported to be lower when self-reporting is assisted could also be influenced by other reasons; among them, a proportion of seniors who may have different coping strategies or limited access to information (included the negative one) among those people who need help should be carefully investigated. 
In our study, the youngest cohorts were the most affected by the epidemic situation, and the senior group proved to be the most stable. This may be due to the fact that seniors have richer life experiences, including coping with difficult situations, and also due to the fact that the emotional balance of older people is less intense than that of younger people (Carstensen et al., 2011). The reason may also be the flood of young people with negative information. Mazza et al. (2020) interpret the reason for higher anxiety in young adults on the grounds of being well informed through social media, which goes hand in hand with overexposure to negative information which can lower resilience. The author also associates a higher level of stress with already present health issues or mental disorders, which is more prevalent in younger cohorts, also in the Czech population (Soldánová, 2019). Orben, Tomova, and Blakemore (Orben et al., 2020) emphasize the important role of social deprivation and loss of personal contact among adolescents aged 10 to 24 in the context of Covid-19, which can significantly affect their mental health. On the contrary, there are also protective factors that can moderate our results. Wang et al. (2020) mention that participants with higher education may be better protected against negative emotions. Higher education people are overrepresented in our study, which could influence the results.

The results indicate that women differ significantly from men in the observed variables, the difference was observed especially for psychological disturbance $(r=0.07)$ and negative emotions $(r=0.08)$. Because we had a much larger sample of women than men, we verified the findings using a randomly generated comparative subsample of women's data; the significances of the differences were the same (except for anxiety in T4).

Although this study brought about a set of interesting findings, gender and age, which are assumed to be important factors that moderate the psychological impact of the pandemic, explained only a negligible percentage of variance, which means that the degree of psychological disturbance is significantly influenced by other factors (specific life situations, personality differences, etc.). In addition to that, the impact of age and gender itself should be further analyzed, as the underlying causation is unclear. It could be, among others, a lack of life experience and coping skills in young adults, isolation helping to control exposure to potential infection and associated fear of infection or feelings of care and protection induced by adopted measures in older people. This will be the subject of a subsequent qualitative analysis of open statements.

There are several limitations in this study. In particular, the impossibility of obtaining a representative and balanced sample, which is also typical for other studies on this topic, and the inevitability to use screening methods of assessing the mental state that do not yet have stratified population normative data for the Czech society. Unbalanced design and social desirability have proven to be complicating factors, as can be seen from the difference between direct and assisted administration of the questionnaire. Age and gender explain only a small part of the variance of people's psychological response to the development of a pandemic situation, and there is necessary to examine other influences, which will be targeted in further analysis.

Other limitations of the study result from the chosen cross-sectional research design, which, unlike longitudinal studies, does not allow a more complex comparison of development and changes over time. In this regard, we present an analysis of data from four independent data collections, which reduces the ability to interpret the results at the level of causal relationships. 
On the other hand, the study has undeniable advantages. It shows the psychological impact on people's emotional well-being and mental state even in the conditions of a relatively wellmanaged protection against pandemics. The results confirm previous findings on the psychological impact of the pandemic on younger age cohorts and on women. In our sample, there was a large representation of students, so further analysis can help to analyse the response of this subpopulation. The benefit of our study is also the fact that it empirically demonstrates the difference between directly and indirectly obtained data in such an emergency situation, which can be used for better understanding of people's responses to similarly serious situations with a high degree of isolation.

\section{Conclusion}

In summary, the study supports evidence that the psychological impact of COVID-19 in the Czech Republic during the spring of 2020 was rather strong and immediate even if the spread of the disease was successfully controlled. Women were more negatively affected than men, and the impact on young adults was greater than on mature adults or seniors. Further investigation of these effects is necessary. In contrast, recovery and return to normal well-being were relatively fast when restrictive measures were released, and the spread of the disease remained mild. This could be culturally dependent and also needs further research.

An important finding of the study shows that the report on negative experience can be significantly downplayed when isolated people cannot answer directly online and are assisted by interviewers. This could have implications for studies that assess especially the well-being of people who need help answering screening measures in emergencies.

\section{Acknowledgments}

We gratefully acknowledge the contribution of Tereza Vospělová and Gabriela Rotterová for their dedicated help to keep a log of adopted measures and data control.

\section{Research Ethics Statement}

The Ethics Committee of the Faculty of Education of the University of South Bohemia has evaluated the submitted project and has come to the conclusion that the project does not contradict existing principles, rules, and regulations or international standards for carrying out research involving human participants (Ethics Committee Official Report EK12/2020, August $13,2020)$.

\section{References}

Al Dhaheri, A. S., Bataineh, M. F., Mohamad, M. N., Ajab, A., Al Marzouqi, A., Jarrar, A. H., HabibMourad, C., Abu Jamous, D. O., Ali, H. I., Al Sabbah, H., Hasan, H., Stojanovska, L., Hashim, M., Abd Elhameed, O. A., Shaker Obaid, R. R., ElFeky, S., Saleh, S. T., Osaili, T. M., \& Cheikh Ismail, L. (2021). Impact of COVID-19 on mental health and quality of life: Is there any effect? A cross-sectional study of the MENA region. PLOS ONE, 16(3), e0249107.

https://doi.org/10.1371/journal.pone.0249107 
Banna, M. H. A., Sayeed, A., Kundu, S., Christopher, E., Hasan, M. T., Begum, M. R., Kormoker, T., Dola, S. T. I., Hassan, M. M., Chowdhury, S., \& Khan, M. S. I. (2020). The impact of the COVID-19 pandemic on the mental health of the adult population in Bangladesh: A nationwide cross-sectional study. International Journal of Environmental Health Research, 1-12. https://doi.org/10.1080/09603123.2020.1802409

Beusenberg, M., Orley, J. H. (1994). A User's guide to the self reporting questionnaire (SRQ). World Health Organization.

Bjelland, I., Dahl, A. A., Haug, T. T., \& Neckelmann, D. (2002). The validity of the Hospital Anxiety and Depression Scale: An updated literature review. Journal of Psychosomatic Research, 52(2), 69-77. https://doi.org/10.1016/S0022-3999(01)00296-3

Bužgová, R., Hajnová, E., Feltl, D., \& Stolička, M. (2014). Faktory ovlivňující úzkost a depresi u pacientů v konečném stadiu nemoci při hospitalizaci. Česká a Slovenská Psychiatrie, 110(5).

Carstensen, L. L., Turan, B., Scheibe, S., Ram, N., Ersner-Hershfield, H., Samanez-Larkin, G. R., Brooks, K. P., \& Nesselroade, J. R. (2011). Emotional experience improves with age: Evidence based on over 10 years of experience sampling. Psychology and Aging, 26(1), 21-33. https://doi.org/10.1037/a0021285

Cosco, T. D., Doyle, F., Ward, M., \& McGee, H. (2012). Latent structure of the Hospital Anxiety and Depression Scale: A 10-year systematic review. Journal of Psychosomatic Research, 72(3), 180184. https://doi.org/10.1016/j.jpsychores.2011.06.008

Dragomirecká, E., Kubisová, D., \& Anděl, M. (2004). Duševní zdraví pražských bezdomovců. Psychiatrie, 8(4), 274-279.

Džuka, J. (2015). Wellbeing in Slovakia. In Global Handbook of Quality of Life (s. 663-684). Springer. https://doi.org/10.1007/978-94-017-9178-6_30

Džuka, J., \& Dalbert, C. (2002). Vývoj a overenie validity škál emocionálnej habituálnej subjektívnej pohody (SEHP). Československá psychologie, 46(3), 234-250.

Fisher, J. R., Tran, T. D., Hammarberg, K., Sastry, J., Nguyen, H., Rowe, H., \& Kirkman, M. (2020). Mental health of people in Australia in the first month of COVID-19 restrictions: A national survey. Medical Journal of Australia, 213(10), 458-464. https://doi.org/10.5694/mja2.50831

Gilan, D., Röthke, N., Blessin, M., Kunzler, A., Stoffers-Winterling, J., Müssig, M., Yuen, K. S. L., Tüscher, O., Thrul, J., Kreuter, F., Sprengholz, P., Betsch, C., Stieglitz, R. D., \& Lieb, K. (2020). Psychomorbidity, resilience, and exacerbating and protective factors during the SARS-CoV-2 pandemic: A systematic literature review and results from the German COSMO-PANEL. Deutsches Aerzteblatt Online, 117(38), 625-632. https://doi.org/10.3238/arztebl.2020.0625

Government of the Czech Republic. (2020). Government of the Czech Republic. https://vlada.cz/en/

Gurková, E., Haroková, S., Džuka, J., \& Žiaková, K. (2014). Job satisfaction and subjective wellbeing among Czech nurses. International Journal of Nursing Practice, 20(2), 194-203. https://doi.org/10.1111/ijn.12133

Harding, T. W., Climent, C. E., Diop, M., Giel, R., Ibrahim, H. H. A., Murthy, R. S., Suleiman, M. A., \& Wig, N. N. (1983). The WHO collaborative study on strategies for extending mental health care: II. The development of new research methods. The American Journal of Psychiatry.

Harpham, T., Reichenheim, M., Oser, R., Thomas, E., Hamid, N., Jaswal, S., Ludermir, A., \& Aidoo, M. (2003). Measuring mental health in a cost-effective manner. Health Policy and Planning, 18(3), 344-349. https://doi.org/10.1093/heapol/czg041

Hayes, A. F., \& Coutts, J. J. (2020). Use omega rather than Cronbach's alpha for estimating reliability. Communication Methods and Measures, 14, 1-24. https://doi.org/10.1080/19312458.2020.1718629

Jacques-Aviñó, C., López-Jiménez, T., Medina-Perucha, L., de Bont, J., Gonçalves, A. Q., DuarteSalles, T., \& Berenguera, A. (2020). Gender-based approach on the social impact and mental health in Spain during COVID-19 lockdown: A cross-sectional study. BMJ Open, 10(11), e044617. https://doi.org/10.1136/bmjopen-2020-044617 
Lieberoth, A., Lin, S., Stöckli, S., Han, H., Kowal, M., Gelpi, R., Chrona, S., Tran, T. P., Jeftić, A., Rasmussen, J., Cakal, H., Milfont, T. L., Yamada, Y., Amin, A., Debone, S., Flis, I., Sahin, H., Turk, F., Yeh, Y.-Y., ...Dubrov, D. (2021). Stress and worry in the 2020 coronavirus pandemic: relationships to trust and compliance with preventive measures across 48 countries in the COVIDiSTRESS global survey. Royal Society Open Science, 8(2), 200589. https://doi.org/10.1098/rsos.200589

Mazza, C., Ricci, E., Biondi, S., Colasanti, M., Ferracuti, S., Napoli, C., \& Roma, P. (2020). A nationwide survey of psychological distress among Italian people during the COVID-19 pandemic: Immediate psychological responses and associated factors. International Journal of Environmental Research and Public Health, 17(9), 3165. https://doi.org/10.3390/ijerph17093165

McCracken, L. M., Badinlou, F., Buhrman, M., \& Brocki, K. C. (2020). Psychological impact of COVID-19 in the Swedish population: Depression, anxiety, and insomnia and their associations to risk and vulnerability factors. European Psychiatry, 63(1). https://doi.org/10.1192/j.eurpsy.2020.81

Meng, H., Xu, Y., Dai, J., Zhang, Y., Liu, B., \& Yang, H. (2020). Analyze the psychological impact of COVID-19 among the elderly population in China and make corresponding suggestions. Psychiatry Research, 289, 112983. https://doi.org/10.1016/j.psychres.2020.112983

NVF-NOZV. (2016). Konkurenčni schopnost České republiky — Kvalita lidských zdrojů. [Competitiveness of the Czech Republic-Quality of human resources.]. http://www.nvf.cz/konkurencni-schopnost-ceske-republiky-2015-vyvoj-hlavnich-indikatoru

Orben, A., Tomova, L., \& Blakemore, S.-J. (2020). The effects of social deprivation on adolescent development and mental health. The Lancet Child \& Adolescent Health, 4(8), 634-640. https://doi.org/10.1016/S2352-4642(20)30186-3

Özdin, S., \& Bayrak Özdin, Ş. (2020). Levels and predictors of anxiety, depression and health anxiety during COVID-19 pandemic in Turkish society: The importance of gender. International Journal of Social Psychiatry, 66(5), 504-511.https://doi.org/10.1177/0020764020927051

Pierce, M., Hope, H., Ford, T., Hatch, S., Hotopf, M., John, A., Kontopantelis, E., Webb, R., Wessely, S., McManus, S., \& Abel, K. M. (2020). Mental health before and during the COVID-19 pandemic: A longitudinal probability sample survey of the UK population. The Lancet Psychiatry, 7(10), 883-892. https://doi.org/10.1016/S2215-0366(20)30308-4

Plomecka, M. B., Gobbi, S., Neckels, R., Radziński, P., Skórko, B., Lazerri, S., Almazidou, K., Dedić, A., Bakalović, A., \& Hrustić, L. (2020). Mental Health Impact of COVID-19: A global study of risk and resilience factors. MedRxiv. https://doi.org/10.1101/2020.05.05.20092023

Qiu, J., Shen, B., Zhao, M., Wang, Z., Xie, B., \& Xu, Y. (2020). A nationwide survey of psychological distress among Chinese people in the COVID-19 epidemic: Implications and policy recommendations. General Psychiatry, 33, e100213. https://doi.org/10.1136/gpsych-2020-100213

Rodríguez-Rey, R., Garrido-Hernansaiz, H., \& Collado, S. (2020). Psychological impact and associated factors during the initial stage of the coronavirus (COVID-19) pandemic among the general population in Spain. Frontiers in Psychology, 11, 1540. https://doi.org/10.3389/fpsyg.2020.01540

Rossi, R., Socci, V., Talevi, D., Mensi, S., Niolu, C., Pacitti, F., Di Marco, A., Rossi, A., Siracusano, A., \& Di Lorenzo, G. (2020). COVID-19 Pandemic and Lockdown Measures Impact on Mental Health Among the General Population in Italy. Frontiers in Psychiatry, 11, 790. https://doi.org/10.3389/fpsyt.2020.00790

Salari, N., Hosseinian-Far, A., Jalali, R., Vaisi-Raygani, A., Rasoulpoor, S., Mohammadi, M., Rasoulpoor, S., \& Khaledi-Paveh, B. (2020). Prevalence of stress, anxiety, depression among the general population during the COVID-19 pandemic: A systematic review and meta-analysis. Globalization and Health, 16(1), 57. https://doi.org/10.1186/s12992-020-00589-w

Serafini, G., Parmigiani, B., Amerio, A., Aguglia, A., Sher, L., \& Amore, M. (2020). The psychological impact of COVID-19 on the mental health in the general population. QJM: An International Journal of Medicine, 113(8), 531-537. https://doi.org/10.1093/qjmed/hcaa201 
Scholte, W. F., Verduin, F., van Lammeren, A., Rutayisire, T., \& Kamperman, A. M. (2011).

Psychometric properties and longitudinal validation of the self-reporting questionnaire (SRQ-20) in a Rwandan community setting: A validation study. BMC Medical Research Methodology, 11(1), 1-10. https://doi.org/10.1186/1471-2288-11-116

Soldánová, L. (2019). Prevalence duševních onemocněnív Česku v závislosti na pohlaví a věku [Prevalence of mental disorders in the Czech population: Age and sex differences]. Bachelor thesis. Charles University, Faculty of Science.

Soukup, P., \& Rabušic, L. (2020). Hodnoty ve světle COVID-19 [Values in the light of COVID-19]. 2020. Charles University, Faculty of Social Science.

https://fsv.cuni.cz/sites/default/files/uploads/files/v\%C3\%BDsledky v\%C3\%BDzkumu Hodnoty _ve_sv\%C4\%9Btle_COVID-19.pdf

Szabó, C., Pukánszky, J., \& Kemény, L. (2020). Psychological effects of the COVID-19 pandemic on Hungarian adults. International Journal of Environmental Research and Public Health, 17(24). https://doi.org/10.3390/ijerph17249565

Talevi, D., Socci, V., Carai, M., Carnaghi, G., Faleri, S., Trebbi, E., di Bernardo, A., Capelli, F., \& Pacitti, F. (2020). Mental health outcomes of the CoViD-19 pandemic. Rivista Di Psichiatria, 55(3), 137-144. https://doi.org/10.1708/3382.33569

Trnka, R., \& Lorencova, R. (2020). Fear, anger, and media-induced trauma during the outbreak of COVID-19 in the Czech Republic. Psychological trauma: theory, research, practice, and policy, 12(5), 546-549. https://doi.org/10.1037/tra0000675

Tsoukalis-Chaikalis, N., Demsia, S. F., Chaniotis, D., \& Chaniotis, F. (2021). Systematic Mapping Study of The Covid-19 Psychological Impact. Health Science Journal, 15(3).

https://www.hsj.gr/abstract/systematic-mapping-study-of-the-covid19-psychological-impact36010.html

Twenge, J., \& Joiner, T. E. (2020). Mental distress among U.S. adults during the COVID-19 pandemic [Preprint]. PsyArXiv. https://doi.org/10.31234/osf.io/wc8ud

Ventevogel, P., De Vries, G., Scholte, W. F., Shinwari, N. R., Faiz, H., Nassery, R., van den Brink, W., \& Olff, M. (2007). Properties of the Hopkins Symptom Checklist-25 (HSCL-25) and the SelfReporting Questionnaire (SRQ-20) as screening instruments used in primary care in Afghanistan. Social Psychiatry and Psychiatric Epidemiology, 42(4), 328-335. https://doi.org/10.1007/s00127$\underline{007-0161-8}$

Wang, C., Pan, R., Wan, X., Tan, Y., Xu, L., Ho, C. S., \& Ho, R. C. (2020). Immediate psychological responses and associated factors during the initial stage of the 2019 coronavirus disease (COVID19) epidemic among the general population in China. International Journal of Environmental Research and Public Health, 17(5), 1729. https://doi.org/10.3390/ijerph17051729

Xiong, J., Lipsitz, O., Nasri, F., Lui, L. M. W., Gill, H., Phan, L., Chen-Li, D., Iacobucci, M., Ho, R., Majeed, A., \& McIntyre, R. S. (2020). Impact of COVID-19 pandemic on mental health in the general population: A systematic review. Journal of Affective Disorders, 277, 55-64. https://doi.org/10.1016/j.jad.2020.08.001

Zigmond, A. S., \& Snaith, R. P. (1983). The hospital anxiety and depression scale. Acta psychiatrica scandinavica, 67(6), 361-370. https://doi.org/10.1111/j.1600-0447.1983.tb09716.x 


\section{About the authors}

Prof. PaedDr. Iva Stuchlíková, CSc. is a professor of educational psychology at the Department of Psychology, Faculty of Education, University of South Bohemia in České Budějovice. She has been involved in research on emotions and motivation, formative assessment, and inquiry-based education. She worked as a principal researcher of several Czech and European research projects focused mainly on emotional and motivational processes and on psychological aspects of instructions. She also works as a therapist in a university psychological counselling centre. Since 2011 she has been working in the Board of Educational Affairs of the European Federation of Psychologists' Association.

E-mail: stuchl@pf.jcu.cz

PhDr. Dalibor Kučera, Ph.D. is a lecturer and researcher in the field of general and social psychology. Since 2013, he has been working as an assistant professor and project investigator at the Department of Psychology of the Faculty of Education at University of South Bohemia in České Budějovice, and as the head of this department since 2021. Since 2012, he has been focused on the area of psychology of language use. In 2020 he was awarded a senior FulbrightMasaryk scholarship of the J. W. Fulbright Commission for the project 'Personality Processes and Oral Communication'. He is a member of the board of the Czech-Moravian Psychological Society.

\section{Corresponding author - contact details}

Address: Department of Psychology, Faculty of Education, University of South Bohemia, Jeronýmova 10, 37115 České Budějovice, Czech Republic E-mail: dkucera@pf.jcu.cz

Mgr. Tomáš Mrhálek, Ph.D. is a lecturer and researcher, who works as an assistant professor at the Department of Psychology of the Faculty of Education at University of South Bohemia in České Budějovice. He has been focused on methodology, psychometrics, and areas of intercultural and general psychology.

E-mail: tmrhalek@pf.jcu.cz

Mgr. Eva Potužníková is a researcher in the field of educational measurement. She has been involved in international large-scale assessment studies of student knowledge and skills and secondary analyses of data from these studies. Since 2020, she has been collaborating with the Department of Psychology, Faculty of Education, University of South Bohemia in České Budějovice.

E-mail: epotuznikova@pf.jcu.cz

Mgr. Michala Plassová, Ph.D. is a lecturer and researcher in the field of general psychology and neuropsychology. Since 2014, she has been working as an assistant professor at the Department of Psychology of the Faculty of Education at University of South Bohemia in České Budějovice. Since 2015, she has been focused on the area of numerosity and cognitive psychology.

E-mail: mplassova@pf.jcu.cz

Stuchlíková, I., Kučera, D., Mrhálek, T., Potužníková, E., \& Plassová, M. (2021). Dynamics of COVID-19's psychological impact in the Czech Republic: Situation during spring 2020. E-psychologie, 15(4), 40-59.

https://doi.org/10.29364/epsy.420 